UDC 534.1, 621.81-192
DOI: $10.29202 /$ nvngu/2018-3/12

1 - O. M. Beketov National University of Urban Economy in Kharkiv, Ukraine, e-mail: v.p.shpachuk@gmail.com 2 - State Enterprise "Kharkiv Morozov Machine Building Design Bureau”, Kharkiv, Ukraine
M. A. Zasiadko ${ }^{1}$, Assoc. Prof., orcid.org/0000-0001-6725-3385, V.V. Dudko

\title{
INVESTIGATION OF STRESS-STRAIN STATE OF PACKET NODE CONNECTION IN SPATIAL VIBRATION SHAKERS
}

Purpose. Using the study of stress-stain state of the CNs (connection nodes) used in multi-axis translational shakers formed as a package of TEEs (tape elastic elements), to formalize dependencies of their mechanical and structural parameters on the range of operating frequencies and the level of transmitted mechanical loads in the shaker node. Additionally, to take into account the impact of the force reproduced by the node on the elastic deformations of the unit considering that a particular tape unit undergoes bending in two planes, as well as displacement and stretching simultaneously. To develop a method for calculating the structural and mechanical parameters of the considered CNs regarding the known values of amplitude and frequency parameters yielded by the stand of dynamic loads.

Methodology. The study is based on the fundamental approaches of applied mechanics, modeling theory, machine dynamics and vibration reliability.

Findings. Dependences of thickness, length and width of the tape elastic elements, as well as their number in the package and the number of packages in the connection node in the direction of the transmitted vibration on the given stiffness and strength characteristics are obtained. A method is developed for calculating structural and mechanical parameters of the elastic elements, taking into account the specified parameters of the amplitude and frequency characteristics of strains reproduced by the stand.

Originality. For the first time, a technique is proposed for calculating structural parameters (thickness, length, width of the tape, the number of elastic elements in the package, the number of packages in the $\mathrm{CN}$ ) and the mechanical characteristics (compliance of the package, the endurance limit of the elastic element material) of the $\mathrm{CN}$, taking into account the frequency range specified by the regulatory document and the levels of vibrational loads reproduced on the platform of the stand. In this case, the stress-strain state of each elastic element of the package includes its work on bending in two planes, displacement and stretching and satisfies the strength and rigidity conditions of the CN altogether. Taking into account the requirements for the preset rigidity of the package in the non-operational direction, and small value of tape thickness, the conditions of durability and rigidity are eventually satisfied due to the possibility to alter a number of tapes in the package. The stiffness of the package of elastic elements as well as the number of packets in the connection node are determined according to the conditions for carrying out vibration tests in the operating frequency ranges and the levels reproduced on the shaker table of mechanical loads.

Practical value. The use of the considered CNs in the form of TEE packages for jointing the tables of vibration exciters with many degrees of freedom with a platform and a platform with a fixed base provides the following advantages: simplicity of manufacture; no additional energy costs for their maintenance; light weight that unloads the table suspension of vibration exciters in the non-working direction, which makes them more reliable; linearity of the stiffness of the node in the transmitted vibration direction. In particular, their use as CNs in joined constructive details of different formations increases reliability, durability and maximum weight capacity of machines, equipment and mechanisms used in mining engineering, as well as vibration, aviation, transport and space technologies.

Keywords: shaker connection nodes, vibration loads, stiffness of elastic elements in a package, range of operating frequencies

Introduction. Vibration is a basic kind of test to probe structures, machineries, components and product units, aiming to determine their ability to perform their functions within the limits of given standards [1], as well as their ability to resist the destructive effects of vibration loads [2]. The exploitation of most modern machinery units, mining equipment, vibration equipment, aviation [3], transport and space machinery [4] operating under the action of spatial vibration when vibration vectors change both in magnitude and direction in time dependence. As a result, [5] elements of CNs of machine unites perform spatial vibration and experience complex

(C) Shpachuk V.P., Zasiadko M.A., Dudko V.V., 2018 stress, including the directions which are not peculiar to a given operating movement. Mechanisms whose components are joined by CNs have particular durability parameters [6], strength and rigidity [7]. These parameters essentially depend on features of the nodes considered here, and these dependencies can be characterized by a linear rule. These parameters significantly affect the accuracy of multi-axis vibration [1] produced by the stand, which ultimately determines the quality of research in the physics of vibration failures [5]. Unlike machines performing vibration and striking [8], rod, electromagnetic [9], greased and lubricated CNs, the ones considered in this paper are made in the form of a package of TEEs. They are distinguished by simplicity of manufac- 
turing, do not require additional energy to maintain their performance, have low weight, and most importantly, they are characterized by linear dependencies of stiffness in the transmitted vibration direction [5]. Solving the problem of design and calculation of spatial shaker CNs and critical machine parts leads to higher reliability and durability of the equipment used in multiaxis dynamic loading conditions. Therefore, this problem is one of the most pressing in modern science and technology.

Analysis of the recent research. The practical use of CNs of spatial shakers shows that they must satisfy the following basic requirement, i.e. the absence of interference between displacement of joined parts in the direction of the transmitted vibration and conjugate directions.

Problems related to the design and calculation of rob, electromagnetic, and greased CNs of multi-axis shakers were solved theoretically [3] and practically [1]. However, the possibility to meet the above mentioned basic requirement is not considered, which reduced the accuracy of the reproduced spatial vibration on the stand and, consequently, the veracity of probing DUTs for vibration reliability tests.

The objective of the paper is to design CNs of vibration exciter tables with a fixed base of two or three-axial translational shakers, which are invariant to the type of testing object, as well as to the range of operating frequencies and the level of vibration loads transmitted by the CN. Another objective is to develop a method for calculating structural and mechanical characteristics of CNs' TEE of joints of spatial shakers with regard to the parameters reproduced on the platform of mechanical loads.

Presentation of the main research. This article is devoted to the study of CNs of spatial translational shakers, formed as a package of TEEs. The analysis of their stressstrain state is conducted with regard to the amplitude and frequency values reproduced on the stand of dynamic loads. The sketch of two-axial translational shaker, with regard to [5], is shown in Fig. 1. Here one can see: 1 and 2 are horizontal and vertical vibration exciters, 3 is the stand platform, 4 and 7 are housing parts of the stand; 5 and 6 are CNs of body parts and vibration exciter tables. The vibration exciters 1 and 2 are made in the form of elastic elements package and strain rollers. The stand vibration exciters are rigidly mounted on a fixed base. However, Fig. 1 does not show connection nodes of the platform on the stationary base with a roller straining device.

Experiments have shown that a wrong design (the number of packets, the number of tape elastic elements in the package), or choosing inadequate geometric (thickness, width, length, configuration) or mechanical (fatigue limit, safety factor of the fatigue strength) parameters of the $\mathrm{CNs}$ lead to fatigue failure of node package or general failure of the whole shaker.

Considering [1], applied to vibrating equipment, geometrical and mechanical parameters of a package of tape elastic elements in each (horizontal and vertical) $\mathrm{CN}$ should satisfy the following rigidity and strength conditions

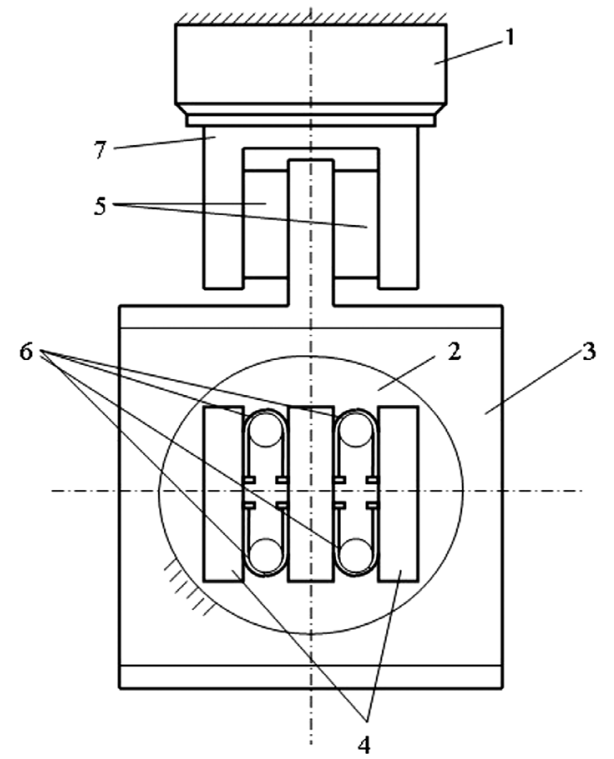

Fig. 1. Sketch of a two-axial shaker

$$
\begin{gathered}
f=\frac{1}{2 \pi}\left(1 /\left(m \delta_{c m}\right)\right)^{1 / 2} \geq f^{*} ; \\
\sigma \leq k^{-1} \sigma_{-1},
\end{gathered}
$$

where $f$ is calculated and $f^{*}$ is given operating frequencies of the shaker; $m$ is the mass of the shaker movable part (e.g. a platform, a testing object, a fastening device); $\delta_{c m}=1 / c$ is $\mathrm{CN}$ static displacement by a force unit; $c$ is $\mathrm{CN}$ stiffness in the direction of transmitted vibration; $\sigma$ is an equivalent stress at $\mathrm{CN} ; \sigma_{-1}$ is endurance limit of node tape material; $k$ is a safety factor of the fatigue strength.

The rigidity condition (1) determines the range of shaker operating frequencies, and the condition (2) is its performance in the given range of operating frequencies and durability.

In the expression (1) $\delta_{c m}$ stands for the unknown shift unit. To determine its value, we need to consider Fig. 2 first. Here $F$ is a force of vibration excitation, directed along its eigen vector, 1 and 2 are fastening constructional details of the connection nodes package, 3 is a package internal tape, 4 is a belt staining roller of radius $r ; M_{1}, M_{2}$ are moments in cross-section elastic element $3 ; R_{y}, R_{x 1}, R_{x 2}$ are reactions of the rod sealing, cor-

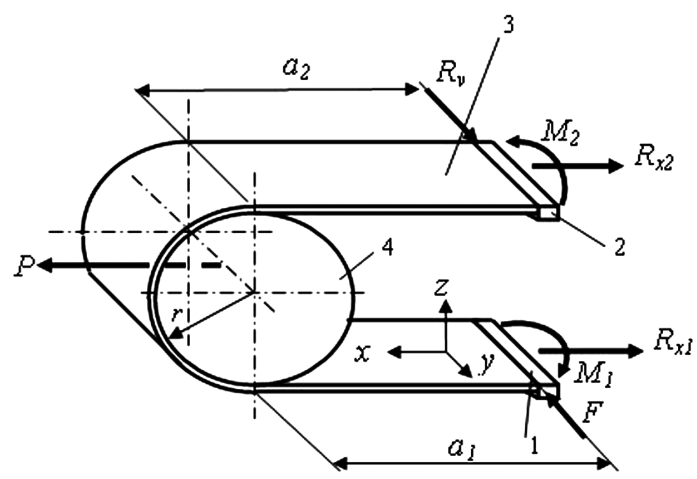

Fig. 2. Mechanical scheme of a package resilient element 
responding to force of vibration excitation $F$ and roller straining force per one package tape $P$. The sketch and Fig. 1 do not demonstrate a strain roller design.

In this case, the presence of roller 4 in Fig. 2 placed between housing components 4 , 7 of the stand shown in Fig. 1 and rigid fixation of fasteners 1,2 ensure the absence of torsion deformation of the package elastic element at sections $a_{1}$ and $a_{2}$ in Fig. 2 .

The force of strip tension by the roller $P$ is determined experimentally at the stage of manufacturing the packages by condition of absence of torque in the cross section of the rod at the kink curved section. As a result, it makes a tight seal of the strip to the tension roller constructively strip in a predetermined range of amplitudes of the vibration excitation force $F$.

From the condition of static equilibrium of element 3 , taking into account its structural symmetry, we find the following identities $M_{1}=M_{2}=M ; R_{y}=F ; R_{x 1}=R_{x 2}=$ $=N=P / 2$.

Besides, in equation (1) $m=F / g$ ( $g$ is gravitational acceleration), and in (2) $F=m a_{\max } / n$, where $a_{\max }$ is the maximum amplitude value reproduced on acceleration stand, $n=n_{1} n_{2}$ is the number of resilient items in $\mathrm{CN}, n_{1}$ is the number of packages in the $\mathrm{CN}$ and $n_{2}$ is the number of tapes in the package.

For separate sections of the curved rod (Fig. 3,a), in its cross sections using [10], we deduce the following expression, longitudinal $N_{x}$ and transverse $Q_{z}, Q_{y}$ forces, bending $M_{z}, M_{y}$ and torques $M_{x}$ :

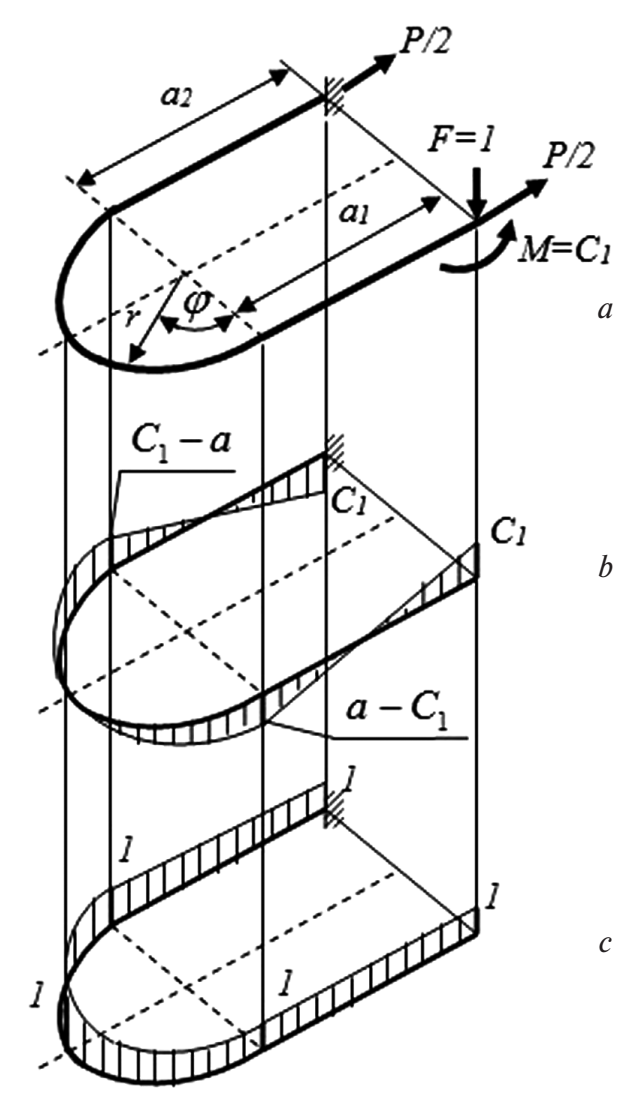

Fig. 3. Diagrams of internal forces: general view of a resilient element (a), diagram of bending moments if $F=1(b)$, diagram transverse forces if $F=1$ (c)
- section 1

$$
\begin{gathered}
\left(0<x<a_{1}\right) ; \quad N_{x}=N ; \quad Q_{z}=0 ; \quad Q_{y}=F ; \\
M_{z}=-M+F x ; \quad M_{y}=0 ;
\end{gathered}
$$

- section 2

$$
\begin{gathered}
(0<\varphi<\pi) ; \quad N_{x \varphi}=N ; \quad Q_{z \varphi}=0 ; \\
Q_{y \varphi}=N ; \quad M_{x \varphi}=0 ;
\end{gathered}
$$

$M_{z \varphi}=-M \cos \varphi+F\left(a_{1}+r \sin \varphi\right) \cos \varphi ; \quad M_{y \varphi}=0 ;$

- section 3

$$
\begin{gathered}
\left(0<x<a_{1}\right) ; \quad N_{x}=N ; \quad Q_{y}=0 ; \quad M_{x}=0 ; \\
M_{z}=M-F\left(a_{1}-x\right) ; \quad M_{y}=0 .
\end{gathered}
$$

According to the moment method [10], it is possible to find the moment $M$ in the kink of the elastic element

$$
M=-\Delta_{1 f} / \delta_{11},
$$

where

$$
\begin{gathered}
\Delta_{1 f}=\sum \frac{1}{E I_{z}} \int \bar{M} M_{f} d s=\frac{1}{E I_{z}}\left[\int_{0}^{a_{1}}(-1) F x d x+\right. \\
\left.+\int_{0}^{\pi}(-\cos \varphi) F\left(a_{1}+r \sin \varphi\right) \cos \varphi r d \varphi+\int_{0}^{a_{2}} 1 \cdot F\left(a_{1}-x\right) d x\right]= \\
=\frac{1}{2 E I_{z}}\left(a_{1}^{2}+2 a_{1} a_{2}-a_{2}^{2}+\pi r a_{1}+4 r^{2} / 3\right) ; \\
=\frac{1}{E I_{z}}\left[\int_{0}^{a_{1}}(-1)^{2} d x+\int_{0}^{a_{2}} 1^{2} d x+\int_{0}^{\pi}(-\cos \phi)^{2} r d \varphi\right]= \\
=\frac{1}{E I_{z}}\left(a_{1}+a_{2}+\frac{\pi r}{2}\right) .
\end{gathered}
$$

The last formula determines turning the end of the strip from $F$ and from unit moment $M=1$, respectively; $E$ and $I_{z}$ are modulus of elasticity of the first kind and the moment of inertia of the element section, respectively.

After transformation we obtain the following

$$
M=C_{1} F,
$$

and when $a_{1}=a_{2}=a$

$$
C_{1}=\frac{a^{2}+\pi r a / 2+2 r^{2} / 3}{2 a+\pi r / 2} .
$$

Fig. $3, b$ shows the diagram of bending moments $M_{z}$, and Fig. 3, $c$ demonstrates the diagram of transverse forces $Q_{z}$ by applying $F=1$.

In the expression (4) we vary the length of the straight section $a$, and straining roller radius $r$, and also the value of vibration force $F$.

In order to determine the eigen frequency $f$ of the shaker in the direction given for the exciter, let us find, using (3), the static rod displacement in Fig. 3 in the same direction when $F=1$. 


$$
\begin{gathered}
\delta_{c m}=\sum \int \mu \frac{\bar{Q}^{2} d s}{G A}+\sum \int \frac{\bar{M}^{2} d s}{E I_{z}}= \\
=\frac{\mu}{G A}\left(\int_{0}^{a_{1}} d x+\int_{0}^{\pi} r d \varphi+\int_{0}^{a_{2}} d x\right)+ \\
+\frac{1}{E I_{z}}\left[\int_{0}^{a_{1}}\left(x-C_{1}\right)^{2} d x+\int_{0}^{a_{2}}\left(C_{1}-a_{1}+x\right)^{2} d x\right]+ \\
+\frac{1}{E I_{z}}\left[\int_{0}^{\pi}\left(-C_{1} \cos \varphi+a_{1} \cos \varphi+r \sin \varphi \cos \varphi\right)^{2} r d \varphi\right],
\end{gathered}
$$

where $G, A$ are absolute values of resilience of the second kind and square of the item cross section; $\mu$ is a tangential stress distribution unevenness coefficient (for rectangular section [10]: $\mu=1,2$ ).

Conducting integration, having $a_{1}=a_{2}=a$, we obtain

$$
\delta_{\tilde{n} \dot{d}}=\frac{\mu}{G A} C_{2}+\frac{1}{E I_{z}} C_{3},
$$

where

$$
\begin{gathered}
C_{2}=2 a+\pi r \\
C_{3}=\frac{2 a^{3}}{3}+\frac{\pi r a^{2}}{2}+\frac{4 r^{2} a}{3}+\frac{\pi r^{3}}{8}- \\
-C_{1}\left(2 a^{2}+\pi r a+\frac{4 r^{2}}{3}\right)+C_{2}^{2}\left(2 a+\frac{\pi r}{2}\right) .
\end{gathered}
$$

While determining the equivalent stress $\sigma$ in (2) we take into account that the tape material undergoes a complex stress state: stretching, bending and displacement (shift, shear). Sectional views shown in Fig. 4, where $h$ and $b$ are the width and thickness of the elastic member, respectively. Depending on the strip aspect ratio, critical sections are places where the tape bends over the roller, and as far as the cross section is concerned, it is the corner point $\mathrm{A}$ and point $\mathrm{B}$ in the middle of the long side.

Here we may select the following forces: the normal stresses of the longitudinal force, bending moment, bending of the strip onto the roller and straining forces on roller force at points $A$ and $B$

$$
\begin{gathered}
\sigma_{x}^{A}=\frac{N}{b h}+F \frac{6 C_{1}}{b h^{2}}+\frac{b E}{2 r} ; \\
\sigma_{z}^{A}=\sigma_{x}^{B}=-\frac{N}{r h} ; \\
\tau_{y}^{B}=\frac{3 F}{2 b h},
\end{gathered}
$$

where the last one is tangential stresses in the point $B$.

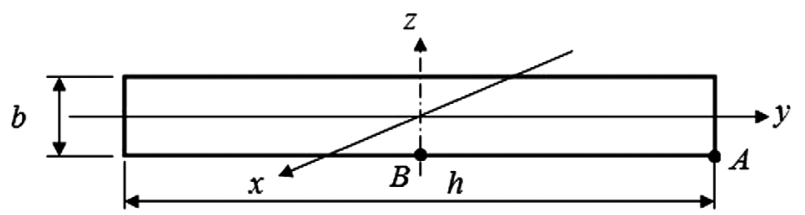

Fig. 4. Resilient element cross section
Equivalent stress $\sigma$ in (2) can be found using the energetic theory of strength [10]

$$
\begin{gathered}
\sigma^{A}=\sqrt{\left(\frac{\sigma_{x}^{A}+\sigma_{z A}}{2}\right)^{2}+3\left(\frac{\sigma_{x}^{A}-\sigma_{z}^{A}}{2}\right)^{2}} ; \\
\sigma^{B}=\sqrt{\left(\frac{\sigma_{x}^{B}+\sigma_{z}^{B}}{2}\right)^{2}+3\left(\frac{\sigma_{x}^{B}-\sigma_{z}^{B}}{2}\right)^{2}+3\left(\tau_{y}^{B}\right)^{2} .}
\end{gathered}
$$

However, the main equation in calculations is (1), which may be reduced to

$$
f=0.15915 \sqrt{\frac{n}{m \delta_{\tilde{n} \dot{0}}}} \geq f^{*} .
$$

Here we can find measures of the number of tapes in the connection node $n$, for the given range of frequencies of the shaker

$$
n \geq 39.48 m \delta_{c m}\left(f^{*}\right)^{2} .
$$

The final value of the number $n$ of strips of tape resilient elements is set as the multiplier of the number of packages in the connection node.

The given condition (2) serves as the verification for the number $n$. Nevertheless, if the condition is not fulfilled, one should use other precision alloys with endurance limit $\sigma_{-1}$. Additionally, one may choose new parameters of width $h$ and height $b$ of the strip.

All the above mentioned routine is iterated until both conditions $(1,2)$ are fulfilled simultaneously.

Calculation. As an example, we consider a two-axial shaker Fig. 1 whose CNs are resilient tape elements.

Let us use the following input parameters for computation: the number of packets in the connection node is 4; geometric parameters are: $a_{1}=a_{2}=3 \cdot 10^{-2} \mathrm{~m} ; b=$ $=2 \cdot 10^{-4} \mathrm{~m} ; h=14 \cdot 10^{-2} \mathrm{~m} ; r=1.25 \cdot 10^{-2} \mathrm{~m} ;$ mechanical parameters are: $k=2 ; \mu=1.2 ; \sigma_{-1}=1610 \mathrm{MPa}$ (the strip is made from dispersion-hardened alloy $40 \mathrm{KXHM}$ ); $f^{*}=800 \mathrm{c}^{-1} ; m=20 \mathrm{~kg} ; E=2 \cdot 10^{11} \mathrm{~Pa} ; G=0.4 E ; F=$ $=4 \cdot 10^{3} \mathrm{~N}$. Let the straining force of the roller be $P=$ $=7000 \mathrm{~N}$. Thus, the longitudinal force $N=3500 \mathrm{~N}$.

According to (1), the computation yields $n=27.5$. If the number of packages in the $\mathrm{CN}$ is 4 , let us assume $n=32$. Consequently, each package should contain 8 strips. Now we should find the number of strips according to the bending radius: $r=1.25 \cdot 10^{-2}+4 b=$ $=1.33 \cdot 10^{-2} \mathrm{~m}$. This gives a corrected number of strips: $n=28.2$. It does not exceed the previous one $n=32$.

Let us now fulfill the verification calculation by condition (2) for the most strained internal strip in the point $B$ of the cross section in Fig. 4 in the place of strip bending over the roller by $\sigma_{-1} / k=805 \mathrm{MPa}$

$$
\sigma^{A}=55.2 \mathrm{MPa}<805 \mathrm{MPa} .
$$

Finally, we may conclude that the received number of resilient elements in the $\mathrm{CN}$ satisfies both stiffness and strength conditions with the safety factor of the fatigue strength $k=2$.

Conclusion. The significance of the research lies in creating a method for calculating structural and me- 
chanical characteristics of $\mathrm{CNs}$ in multi-axis translational shakers, formed as a package of TEE. Herewith we take into account the preset parameters of the amplitude and frequency of vibration loads produced by the shaker. The obtained results can be used in practical application as the basis for constructing two and threeaxial shakers for vibration resistance tests, vibration resistance, and vibration analysis of DUTs operating under the conditions of spatial vibration.

\section{References.}

1. Shpachuk, V.P., 2016. Effect of mutually amplifying action two coordinate shock loading in problems of dynamics of knots of machines. Naukovyi Visnyk Natsionalnoho Hirnychoho Universytetu, 6(156), pp. 89-94.

2. Batt, G., 2016. Simultaneous Multi-TranslationalAxis Motion used in the Evaluation of Product Component Frequency Response and Unit Load Stability. International Journal of Advanced Packaging Technology, 4(1), pp. 200-215.

3. Hoksbergen, J., 2014. Defining the Global Error of a Multi-Axis Vibration Test. Sound \& Vibration, September 2014, pp. 8-13.

4. Venkat, Varun, Singh, A. K., Srikrishna, Mudda, S. and Jhorar, R., 2016. Design, Analysis and Testing of Multiaxis Vibration Fixture for Electronic Devices. Indian Journal of Science and Technology, September 2016, pp. 1-7.

5. Shpachuk, V.P., Dudko, V.V. and Kostenko, I. V., 2015. Methods and installations for tests for multicoordinate external vibrational influence. Komunal'ne hospodarstvo mist, 120, pp. 12-20.

6. Kuzio, I. V., Lanets, O. V. and Gurskyi, V. M., 2013. Synthesis of low-frequency resonance vibratory machines with an aeroinertia drive. Naukovyi Visnyk Natsionalnoho Hirnychoho Universitetu, 2, pp. 60-67.

7. Vinogradov, B. V., 2015. The equivalent number of stress cycles in view of fatigue calculation of tumbling mill gear. Naukovyi Visnyk Natsionalnoho Hirnychoho Universytetu, 1, pp. 72-76.

8. Hurskyi, V. M. and Kuzio, I. V., 2016. Analysis of strength and endurance of leaf string under percussion stress. Skhidno-Yevropeiskyi zhurnal peredovykh tekhnolohii, 5(7(83)), pp. 4-10.

9. Myagkohleb, K. B., 2013. Decrement and stiffness of an electromagnetic shaker with reaction mass. Problemy mashinostroeniya, 2, pp. 30-34.

10. Bazhenov, V.A., Perelmuter, A.V. and Shyshkov, O. V., 2014. Structural mechanics. Computer technologies and modelling. Kyiv: SKAD SOFT.

\section{Дослідження напружено-деформованого стану пакетних вузлів з'єднання просторових вібростендів}

\footnotetext{
В. П. Шиачук ${ }^{1}$, М. А. Засядько ${ }^{1}$, В. В. Дудко

1 - Харківський національний університет міського господарства імені О.М.Бекетова, м. Харків, Україна, e-mail: v.p.shpachuk@gmail.com

2 - Державне підприємство „Харківське конструкторське бюро з машинобудування імені О.О.Морозова“, м. Харків, Україна
}

Мета. Формалізувати на базі дослідження напружено-деформованого стану вузлів з'єднання багатокоординатних поступальних вібростендів, виконаних у вигляді пакетів стрічкових пружних елементів, залежність їх механічних і конструктивних параметрів від діапазону робочих частот і рівня механічних навантажень, що передаються вузлами вібростенда. Урахувати при цьому вплив відтвореного вузлом зусилля на пружні деформації окремого стрічкового елемента, що має одночасно згин у двох площинах, а також зсув і розтягнення. Розробити методику розрахунку конструктивних і механічних параметрів розглянутих вузлів з'єднання 3 урахуванням заданих значень амплітудних і частотних характеристик, відтворюваних стендом динамічних навантажень.

Методика. Дослідження базуються на фундаментальних підходах прикладної механіки, теорії моделювання, динаміки машин і вібраційної надійності.

Результати. Отримані залежності податливості вузла з'єднання в напрямку переданої вібрації, товщини, довжини й ширини стрічкових пружних елементів, а також їх кількості в пакеті й кількості пакетів у вузлі з'єднання від заданих характеристик міцності й жорсткості. Створена методика розрахунку конструктивних і механічних параметрів розглянутих пружних елементів, що враховує параметри амплітудних і частотних характеристик відтворюваних стендом навантажень.

Наукова новизна. Уперше створена методика розрахунку конструктивних параметрів (товщина, довжина, ширина стрічки, кількість пружних елементів у пакеті, кількість пакетів у вузлі з'єднання) і механічних характеристик (податливість пакету, межа витривалості матеріалу пружного елемента) вузла з'єднання з урахуванням заданих нормативним документом: діапазону робочих частот і рівнів відтворюваних на платформі стенда вібраційних навантажень. При цьому напружено-деформований стан кожного пружного елемента пакету включає його роботу на згин у двох площинах, зсув і розтягування та задовольняє умовам міцності й жорсткості вузла з'єднання в цілому. 3 урахуванням вимог до заданої жорсткості пакета в неробочому напрямку, а також малої товщини кожної стрічки, умови довговічності й жорсткості задовольняються, у кінцевому підсумку, за рахунок кількості стрічок у пакеті. Жорсткість пакету пружних елементів, а також кількість пакетів у вузлі з'єднання визначаються з умови проведення вібраційних випробувань у діапазонах робочих частот і рівнів, відтворюваних на платформі стенду механічних навантажень.

Практична значимість. Застосування розглянутих вузлів з'єднання у вигляді пакетів стрічкових пружних елементів для зчленування столів збудників коливань просторових вібростендів із платформою і платформи з нерухомою підставою забезпечує, на відміну від стрижневих, електромагнітних, а також притертих і змащених вузлів з'єднання, такі 
переваги: простота виготовлення; відсутність витрат додаткової енергії на підтримку працездатності вузла; його незначна вага, що розвантажує підвіску столів збудників стенду в неробочому напрямку, тобто робить їх більш надійними; лінійність характеристики жорсткості вузла в напрямку переданої вібрації. Їх використання, наприклад, в якості вузлів з'єднання деталей конструкцій та агрегатів, що зчленовуються, підвищує надійність, довговічність і несучу здатність в експлуатації машин, обладнання й механізмів гірничого машинобудування, вібраційної, авіаційної, транспортної й космічної техніки.

Ключові слова: вузли з'єднання вібростенда, вібраційні навантаження, жорсткість пакету пружних елементів, діапазон робочих частот

\section{Исследование напряженно- деформированного состояния пакетных узлов соединения пространственных вибростендов}

\section{В. П. Шиачук ${ }^{1}$, Н. А. Засядько ${ }^{1}$, В. В. Дудко}

1 - Харьковский национальный университет городского хозяйства имени А.Н.Бекетова, г. Харьков, Украина, e-mail: v.p.shpachuk@gmail.com

2 - Государственное предприятие „Харьковское конструкторское бюро по машиностроению имени А. А. Морозова“, г. Харьков, Украина

Цель. Формализовать на базе исследования напряженно-деформированного состояния узлов соединения многокоординатных поступательных вибростендов, выполненных в виде пакетов ленточных упругих элементов, зависимость их механических и конструктивных параметров от диапазона рабочих частот и уровня передаваемых узлом вибростенда механических нагрузок. Учесть при этом влияние воспроизводимого узлом усилия на упругие деформации отдельного ленточного элемента, испытывающего одновременно изгиб в двух плоскостях, а также сдвиг и растяжение. Разработать методику расчета конструктивных и механических параметров рассматриваемых узлов соединения с учетом заданных значений амплитудных и частотных характеристик, воспроизводимых стендом динамических нагрузок.

Методика. Исследования базируются на фундаментальных подходах прикладной механики, теории моделирования, динамики машин и вибрационной надежности.

Результаты. Получены зависимости податливости узла соединения в направлении передаваемой вибрации, толщины, длины и ширины ленточных упругих элементов, а также их количества в пакете и количества пакетов в узле соединения от заданных жесткостных и прочностных характеристик.
Создана методика расчета конструктивных и механических параметров рассматриваемых упругих элементов, учитывающая заданные параметры амплитудных и частотных характеристик воспроизводимых стендом нагрузок.

Научная новизна. Впервые предложена методика расчета конструктивных параметров (толщина, длина, ширина ленты, количество упругих элементов в пакете, количество пакетов в узле соединения) и механических характеристик (податливость пакета, предел выносливости материала упругого элемента ) узла соединения с учетом заданных нормативным документом: диапазона рабочих частот и уровней воспроизводимых на платформе стенда вибрационных нагрузок. При этом напряженнодеформированное состояние каждого упругого элемента пакета включает его работу на изгиб в двух плоскостях, сдвиг и растяжение и удовлетворяет условиям прочности и жесткости узла соединения в целом. С учетом требований к заданной жесткости пакета в нерабочем направлении, а также малой толщины каждой ленты, условия долговечности и жесткости удовлетворяются, в конечном итоге, за счет количества лент в пакете. Жесткость пакета упругих элементов, а также количество пакетов в узле соединения определяются из условия проведения вибрационных испытаний в диапазонах рабочих частот и уровней, воспроизводимых на платформе стенда механических нагрузок.

Практическая значимость. Применение рассмотренных узлов соединения в виде пакетов ленточных упругих элементов для сочленения столов возбудителей колебаний пространственных вибростендов с платформой и платформы с неподвижным основанием обеспечивает, в отличие от стержневых, электромагнитных, а также притертых и смазанных узлов соединения, следующие преимущества: простота изготовления; отсутствие затрат дополнительной энергии на поддержание работоспособности узла; его незначительный вес, что разгружает подвеску столов возбудителей стенда в нерабочем направлении, то есть делает их более надежными; линейность характеристики жесткости узла в направлении передаваемой вибрации. Их использование, например, в качестве узлов соединения сочленяемых деталей конструкций и агрегатов, повышает надежность, долговечность и несущую способность в эксплуатации машин, оборудования и механизмов горного машиностроения, вибрационной, авиационной, транспортной и космической техники.

Ключевые слова: узлы соединения вибростенда, вибрационные нагрузки, жесткость пакета упругих элементов, диапазон рабочих частот

Рекомендовано до публікації докт. техн. наук М. К. Сухоносом. Дата надходження рукопису 02.03.17. 